\title{
Development of Rapid Agglutination Test to Detect Chicken Marek Antibody
}

\author{
I WAYAN TEGUH WIBAWAN ${ }^{1}$, LIA SITI HALIMAH ${ }^{2}$, \\ TITIEK DJANNATUN ${ }^{3}$, AND KAMALUDDIN ZARKASIE ${ }^{4}$
}

\author{
${ }^{1}$ Laboratory of Microbiology, Department of Infectious Diseases and Veterinary Public Health, \\ Faculty of Veterinary Medicine, Institut Pertanian Bogor, Jalan Agatis, Darmaga Campus, Bogor 16680, Indonesia; \\ ${ }^{2}$ PT. BIOFARMA Persero, Jalan Pasteur 28, Bandung 40161, Indonesia; \\ ${ }^{3}$ Faculty of Medicine, Universitas YARSI, Jalan Letjen Suprapto, Cempaka Putih, Jakarta Pusat 10510, Indonesia; \\ ${ }^{4}$ PT. IPB-Shigeta Animal Pharmaceutical Bogor, Jalan Agatis, Darmaga Campus, Bogor 16680, Indonesia
}

\begin{abstract}
To our knowlege, there is no rapid agglutination test to detect antibodies to viruses which might be due to the small dimension of viral particles. Through complex formation of Staphylococcus aureus bearing protein A-rabbit IgG-anti IgY-IgY anti Marek virus, agglutination of antibodies to viruses can be achieved and visualized. To design the prototype of the test, the bacterial cells of Staphylococcus aureus were coupled to a complex compound consisting of IgG-IgY-Marek antigen. This protocol was able to detect clearly the presence of Marek antibody in chicken sera, showing the rapid, clear and distinct agglutination reaction on the glass objects. No agglutination reaction was observed in the reaction of specified pathogen free chicken sera with this prototype showing the specificity of the test. This finding demonstrates a novel rapid agglutination which can be used for the detection of antibodies to various agents.
\end{abstract}

Key words: indirect coagglutination method, protein A, Staphylococcus aureus, prototype diagnostic kit

The use of specified pathogenic free (SPF) chickens are absolutely necessary in the vaccine industries. The chicken must be monitored regularly for their immunological status by detecting the presence of specific antibody to certain agents.

The World Health Organization (WHO) in its Technical Series Report (TRS) No. 840 (1994) stated that SPF chicken used in the pharmaceutical industry must be free from and have no history of contact with Adeno virus, Reo virus, infectious laryngotracheitis virus, reticuloendotheliosis virus, infectious bursal disease virus, Marek virus, Newcastle Disease virus, Haemophylus gallinarum, influenza and para influenza virus, Salmonella, Mycoplasma, Retro virus, Avian Encephalitis virus and pox virus. Various, and sometimes complicated, serological tests are needed in the monitoring of those agents (Takase et al. 2000). Based on this, an indirect coagglutination test has been developed as a simple and rapid method for detecting various specific antibodies in the animal laboratory and could be used as an appropriate test in the monitoring of health and the immunological status of animal models.

Protein A is well known as one of the surface components of the cell wall of bacteria and is found in Staphylococcus aureus (Kusunoki et al. 1992; Scriba et al. 2008). Protein A is a polypeptide with a molecular weight of $13-45 \mathrm{kDa}$, and binds covalently with the cell wall of bacteria such as $S$. aureus (Forsgren 1970; Boyle and Reis 1987; Kusunoki et al. 1992; Takeuchi et al. 1995). Protein A has an important role in the mechanism of infection, binding the crystallizable fragment (Fc) of mammalian IgG, but not Fc of Ig Y from chicken (Boyle et al. 1985). Protein A is able to bind the Fc of IgA and IgM (Langone et al. 1978). Protein A binds the Fc of IgG, such that the epitope in antigen binding fragment $(\mathrm{Fab})$ is still free

"Corresponding author:, Phone: +62-251-8629474,

Fax: +62-251-8629459, E-mail: wibawan@yahoo.com and has capacity to bind specific antigens (Ribeiro and Araújo Jr 2009).

Coagglutination testing is a simple and rapid method in detecting antigen with a high accuracy of test results. Up to now, $S$. aureus Cowan I is mostly used and known as a rich protein A $S$. aureus strain. However, to date and only very limited information is available on the the possibility of using field strains of $S$. aureus for coagglutination tests.

\section{MATERIALS AND METHODS}

Bacterial Isolates. In this study, 26 Staphylococcus aureus isolates were used; 24 isolates were from humans and 2 isolates from bovines showing subclinical mastitis. All isolates had been identified previously as $S$. aureus, and existed as a collection of Fakultas Kedokteran Hewan, Institut Pertanian Bogor (Djannatun 2002).

Re-Identification of Isolates. Bacteria were inoculated onto blood agar plates for $18 \mathrm{~h}$ at $37^{\circ} \mathrm{C}$, and the type of colony formation and type of haemolysis were observed. The characteristics of bacteria were determined microscopically with Gram staining, and the ability to utilize glucose and mannitol and the expression of catalase and coagulase activities (Qian et al. 2007).

Detection of Protein A with Soft-Agar and Serum Soft-Agar. To determine $S$. aureus strains containing protein A, soft-agar (SA) and serum soft-agar (SSA) techniques are used. Bacterial suspension (1 loop, $10^{9} \mathrm{cfu}$ ) was inoculated into $10 \mathrm{~mL}$ of soft-agar (Brain Heart Infussion /BHI+0.15\%) (Gibco Europe, Karlsruhe, FRG) or into $10 \mathrm{~mL}$ of serum soft-agar $(\mathrm{BHI}+0.15 \%$ agar+100ul rabbit serum), agitated using a vortex and incubated at $37^{\circ} \mathrm{C}$ for $18 \mathrm{~h}$. The bacteria containing protein A will show the changes of colony formation from diffuse in SA to compact in SSA. The negative strains will remain as diffuse colonies in SA as well as in SSA. For further investigation, 3 isolates containing protein $A$ will be selected 
and used as carriers (agglutinators) for the preparation of the prototypes of kits. The consistency of the binding character of the selected isolates will be confirmed in SSA using different species of mammalian sera (Opdebeeck et al. 1988).

Detection of Protein A with Dot Blot Test. The presence of protein A on the cell surface of bacteria was confirmed with the dot blot test. The bacterial suspension $(100 \mu \mathrm{L})$ were dropped onto a nitrocellulose membrane (Bio-Rad, USA), dried, submerged in skimmed milk 3\% (v/v 1:10 in phosphate buffer saline/PBS), washed $2 x$ with $5 \mathrm{~mL}$ PBS. Nitrocellulose membranes were submerged in $5 \mathrm{~mL}$ PBS, incubated with $200 \mu \mathrm{L}$ rabbit serum for $60 \mathrm{~min}$, washed with $5 \mathrm{~mL}$ PBS $(2 \mathrm{x})$ and incubated with mice-anti-rabbit conjugate $(25 \mathrm{~mL}$ conjugate $+5 \mathrm{~mL}$ larutan $\mathrm{PBS}$ ) (BioRad, USA) for $60 \mathrm{~min}$, followed by $2 \mathrm{x}$ washing with $5 \mathrm{~mL}$ PBS. The interaction of protein A and $\mathrm{IgG}$ was visualized by adding $5 \mathrm{~mL}$ of $\alpha$-chloronapthol $(9 \mathrm{~mL} \alpha$-chloronapthol $+3 \mathrm{~mL}$ metanol $+25 \mathrm{~mL}$ PBS) and $200 \mu \mathrm{L}$ of $\mathrm{H}_{2} \mathrm{O}_{2}$ (Towbin et al. 1979).

Purification of Immunoglobulin Y Using Ion Exchange Chromatography. The purification of IgY anti-Marek's antibodies from the chicken sera was done by ion-exchange chromatography DEAE-cellulose/Sephadex G-25 (Amersham Biosciences KK Tokyo, Japan). Using an ammonium sulphate with final concentration $65 \% \mathrm{IgY}$ (obtained from $20 \mathrm{~mL}$ of chicken sera) precipatate which had been resuspended with 20 mL PBS (pH 7.5-8) DEAE-cellulose/Sephadex G-25 gel $(40 \mathrm{~mL})$ was added to $250 \mathrm{~mL}$ distillated water, washed $3 \mathrm{x}$ with distillated water, followed by washing with $50 \mathrm{~mL}$ of $1 \mathrm{M}$ $\mathrm{NaOH}$ and $50 \mathrm{ml}$ of $1 \mathrm{M} \mathrm{HCl}$. Finally, the gel was suspended in $40 \mathrm{~mL}$ of phosphate buffer $(\mathrm{pH} 8)$ and put in a $50 \mathrm{~cm}$ column with a diameter of $22 \mathrm{~cm}$. Gel was washed with Tris $10 \mathrm{mM}$ until clear, $5 \mathrm{~mL}$ ammonium sulphate precipated chicken sera was added to the column and left for the IgY to bind to DEAE beads. The column was washed with Tris $10 \mathrm{mM}$ to release the unbound proteins. The bound IgY was eluted with $200 \mathrm{mM} \mathrm{NaCl}$ in Tris $10 \mathrm{mM}$. The eluate was collected, dialysed and stored until used (Ko and Ahn 2007).

Protein Characterization in SDS-PAGE. The purified IgY was measured for purity using Spectrophotometer. For this, a $100 \mu \mathrm{L}$ aliquot of eluate was added to a cryol tube containing $100 \mu \mathrm{L}$ distillated water. The peak of the protein was detected at $280 \mathrm{~nm}$. The specificity of purified proteins (IgY anti-Marek's antibodies) was determined with agar gel precipitation test (AGPT). The proteins were analysed by sodium dodecyl sulfate-polyacrylamide gel electrophoresis (SDS-PAGE) using 3\% (v/v) loading gel and 10\% (v/v) separating gel and staining with Coomasie Brilliant Blue (Laemmli 1970).
Preparation of Ig GSpecific to IgY. Rabbits were vaccinated in the first week with $0.5 \mathrm{~mL}$ purified $\mathrm{IgY}\left(1 \mathrm{mg} \mathrm{mL}^{-1}\right.$, intra vena/iv), the vaccination was repeated in the second week and the third week with $0.5 \mathrm{~mL}$ purified $\operatorname{IgY}(3 \mathrm{x}$, iv), respectively. One week after the last vaccination, the serum was collected and tested for the presence of specific antibody (IgG) against IgY using the agar-gel-precipitation test (AGPT) (Zhou et al. 1994).

Preparation of Carriers-Matrix. Staphylococcus aureus with protein A present is used as carrier matrix coupled to the complex IgG-IgY-Marek chicken antigen. The bacteria was preserved using formaldehyde $0.5 \%$ (v/v) for $60 \mathrm{~min}$ (Ansorg and Zarifoglu 1986). To avoid the self agglutination, box titration was done to find the appropriate composition of bacterial suspension, rabbit sera, IgY and Marek virus, and this complex agglutinator is known as prototype for proposed diagnostic kits.

Specificity of Prototype Diagnostic Kits. To test the specificity of the prototype, the positive chicken sera, containing specific IgY to Marek virus and control sera from SPF chickens are used. One drop (25 ul) of the prototype solution was placed on a glass object and left to react with one drop of positive serum. The negative serum was used as control. The positive reaction will appear within $1 \mathrm{~min}$, as a clear and distinct agglutination reaction.

\section{RESULTS}

Detection of Protein A with Soft -Agar and Serum Soft -Agar. All Staphylococcus aureus isolates used in this study showed turbid growth in Todd Hewith broth (THB). From 24 S. aureus samples of human origin, 17 isolates showed the change of colony formation from diffuse to compact after the presence of rabbit sera in SSA. Similar results were found for 2 isolates of bovine origin, and by the reference using SA Cowan I strain. No comparable results were found for 7 isolates of human origin and for S. epidermidis, the colonies remained diffuse after the addition of rabbit sera in SSA. No change of colony formation was detected after the addition of chicken sera for all isolates used in this study (Table 1).

From 17 S. aureus isolates containing protein-A, 3 isolates were selected for preparation of carriers matrix, i.e. SA 53, SA 54 and 2Pi1 based on the phenotype expression of the colonies in SSA. To detect the consistency of the binding characters, the isolates were grown in SSA using various mammalian sera. All isolates showed the change of colony formation in SSA using the respective mammalian sera, but not for chicken sera and S. epidermidis (Table 2).

Table 1 The use of soft-agar and serum soft-agar techniques to detect the presence of protein A in Staphylococcus aureus isolates

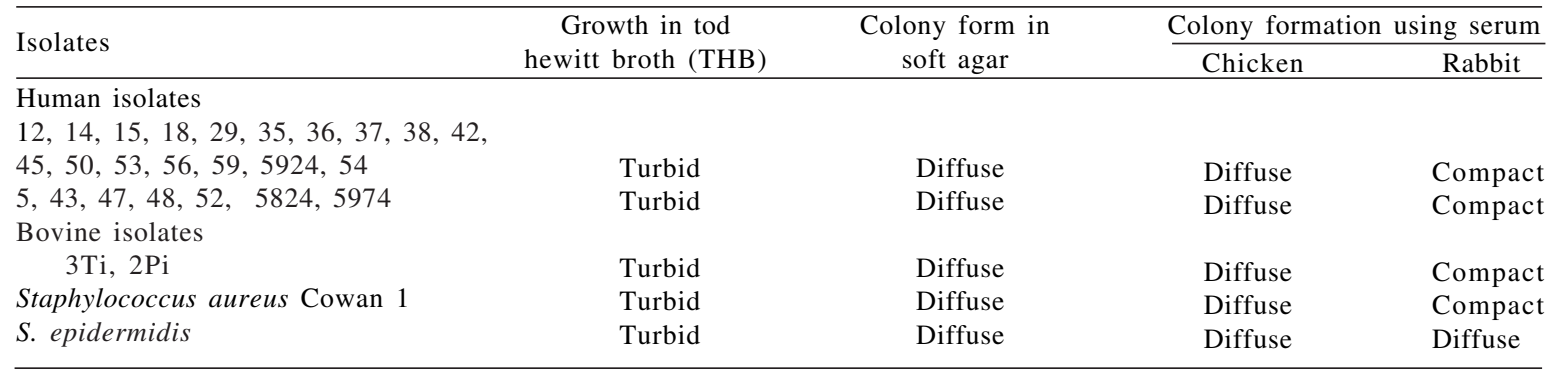


Table 2 The interaction of selected Staphylococcus aureus isolates with various mammalian sera in serum soft-agar

\begin{tabular}{|c|c|c|c|c|}
\hline \multirow{2}{*}{ Test } & \multicolumn{3}{|c|}{ Colony form of S. saureus } & \multirow{2}{*}{ S.epidermidis ${ }^{2}$} \\
\hline & SA 53 & SA 54 & SA 2Pi1 & \\
\hline Soft-agar & Diffuse & Diffuse & Diffuse & Diffuse \\
\hline \multicolumn{5}{|l|}{ Serum soft-agar } \\
\hline Serum & Compact & Compact & Compact & Diffuse \\
\hline Horse & Compact & Compact & Compact & Diffuse \\
\hline Elephant & Compact & Compact & Compact & Diffuse \\
\hline Sheep & Compact & Compact & Compact & Diffuse \\
\hline Rabbit $^{1}$ & Compact & Compact & Compact & Diffuse \\
\hline Dog & Compact & Compact & Compact & Diffuse \\
\hline Guinea pig & Compact & Compact & Compact & Diffuse \\
\hline Chicken & Diffuse & Diffuse & Diffuse & Diffuse \\
\hline
\end{tabular}

For further confirmation, 3 selected isolates were tested for the presence of protein A using the dot blot assay. All isolates showed the presence of protein A. These results are consistent with the results of previous experiments using SSA (Table 3, Fig 1).

Purification of Immunoglobulin Y. The purification of IgY began with the precipitation process using ammonium sulphate which was followed by the separation step using DEAE-cellulose/Sephadex G-25. The purified IgY showing the maximum absorbance at $\lambda 280 \mathrm{~nm}$ had protein concentration of 2.9-5.4 $\mathrm{mg} \mathrm{mL}^{-1}$. This purified IgY reacted specifically with Marek's antigen in AGPT (data not shown). Using electrophoresis and Coomassie blue staining, the purified IgY was found to consist of one main protein band with molecular weight of $97 \mathrm{kD}$ (Fig 2).

IgG specific to IgY. One week after the last vaccination of rabbits using purified $\operatorname{IgY}$, the specific $\operatorname{IgG}$ to $\operatorname{IgY}$ was detected in the sera detected with immunodiffusion tests. The serum was collected and used for the preparation of prototype diagnostic-kits.

In order to find out if the IgG-anti-IgY in the rabbit sera had a consistent characters to bind protein $\mathrm{A}, 100 \mu \mathrm{L}$ of serum was used in SSA which caused the change of colony formation of SA 53, compared to the S. epidermidis. SA 53

Table 3 The presence of protein A in the selected Staphylococcus aureus isolates using dot blot assay

\begin{tabular}{lcc}
\hline Isolates & \multicolumn{2}{c}{ Dot Blot } \\
\cline { 2 - 3 } & Rabbit serum & Chicken serum* \\
\hline SA 2Pi & + & - \\
SA 53 & + & - \\
SA 54 & + & - \\
S. epidermidis & - & - \\
\hline,+ S. aureus Cowan I (dot blott + ); &,- S. epidermidis \\
(dot blott - ); & *Chicken & serum cannot bind the \\
protein A. &
\end{tabular}
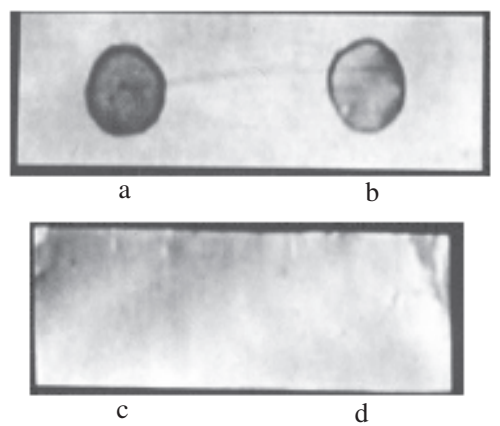

Fig 1 The presence of protein A in SA 53 isolate (b) and no protein A in SA 43 (c). As positive contol SA Cowan I is used (a) and Staphylococcus epidermidis used as a negative control (d). was selected and used for the preparation of prototype reactants of the future diagnostic kits (Fig 3).

Prototype of Diagnostic Kits. The prototype was designed by combining the components $\mathrm{A}$ and $\mathrm{B}$. Component A was prepared by coupling the bacterial cells of SA53 $\left(10^{9} \mathrm{cfu}\right)$ with rabbit sera containing IgG-anti-IgY with the

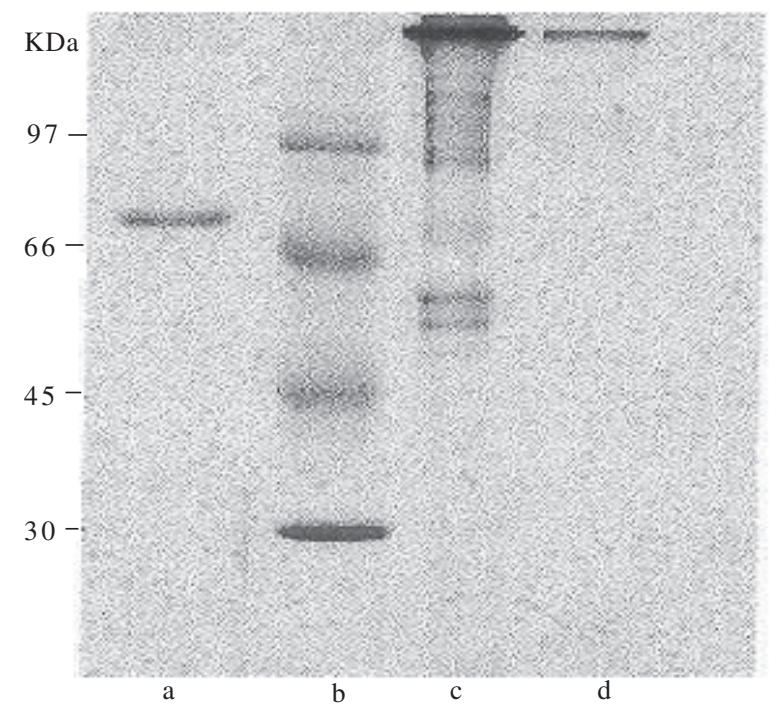

Fig 2 Protein bands of chicken serum after ammonium precipitation (c) and after the DEAE-Cellulose purification (d), pure albumin was used as control (a) and markers were run in line b.

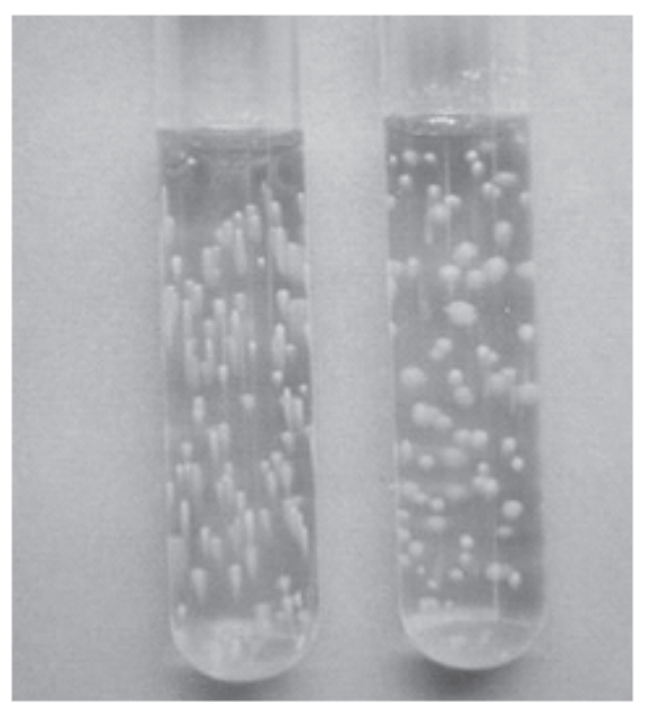

Fig 3 Compact colonies of SA 53 in serum soft agar (SSA) using rabbit sera containing IgG-anti IgY, Staphylococcus epidermidis colonies renmain diffuse in SSA. 
composition 4:1 (v/v), incubated for 60 min. Component B was prepared by incubating purified specific IgY with the suspension of Marek virus. The relative compositions of component A and B were monitored and optimalized with box titration in order to avoid self agglutination reactions.

Application of the Test. The specificity of the prototype reactants was undertaken by determining the presence of specific IgY in chicken serum. This serum was obtained from chickens which were previously vaccinated with Marek's disease virus. For the negative control, the sera from SPF chickens used was kindly provided by PT Biofarma Persero, Bandung. The test results showed that, a specific clear and distinct agglutination reaction can be seen in positive Marek serum 1 min after the addition of one drop of the kit suspension onto a glass object (Fig 4). In contrast, no agglutination reaction can be detected in control sera and the suspension of kits remain homogeneous after 5 min of observing.

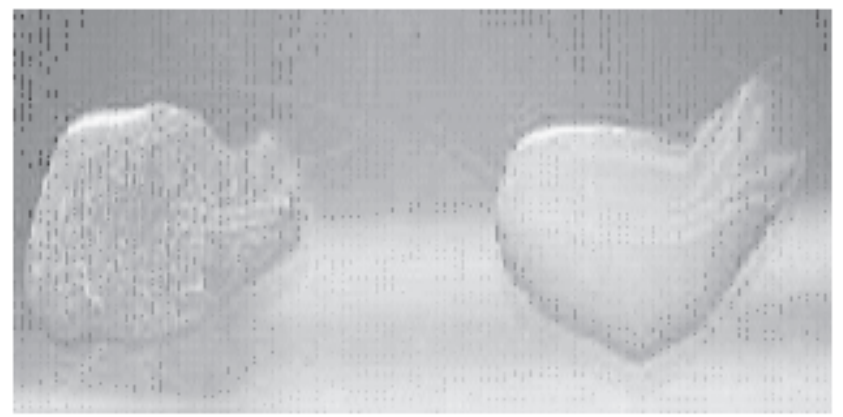

Fig 4 Agglutination reaction of chicken sera containing Marek antibody with prototype diagnostic kits (left) and no agglutination reaction in serum specified pathogen free chicken (right).

\section{DISCUSSION}

The gamma globulin $(\gamma \mathrm{IgG})$ binding capability of surface component (protein A) found frequently on the cell wall of certain strains of $S$. aureus has been exploited for serodiagnosis of several bacterial and viral diseases. This coagglutination method was used mainly to detect specific antigens. However, in the present communication indirect coagglutination method is developed to detect the presence of specific antibodies in chicken serum with the Marek's disease antibody being used as a model.

We endeavoured to search the scientific literatures about the use of an indirect approach in the coagglutination test, but there is only very limited information about the use of indirect coagglutination for sero-diagnosis. Indirect agglutination has already been used in the development haemagglutination techniques, indirect ELISA, indirect immunomagnetic separation, latex agglutination and for indirect immunofluorescence (Rufli 1980; Del Río et al. 2003; Jesudason et al. 2005; Datta et al. 2008; Kerremans et al. 2008).

The problem in the monitoring of the serological status of laboratory animal is the use of various methods for certain agents, and the use of complicated and expensive methods. Indirect coagglutination methods could be considered as an alternative and a simpler method that might be used in the monitoring of specific antibodies in the animal laboratory. The use of $S$. aureus containing protein A as an agglutinator, as part of important components in the prototype design is possible. One the other hand, it is impossible to design the direct agglutination using IgY of chickens because IgY that cannot bind protein A. (Djannatun 2002).

Staphylococcus aureus containing protein A is very important for this test. In this study we developed the simple method of using serum soft-agar techniques to detect the strains of $S$. aureus bearing protein A. This study showed that the change of colony formation of bacteria from diffuse to compact in SSA could be used an an indicator to select $S$. aureus isolates containing protein A. This indicator was confirmed by using the purified rabbit $\mathrm{IgG}$, the change of colony formation of protein A-positive-strains was also observed after the addition of purified IgG in SSA (data not shown). This indicated that the interaction of $\mathrm{IgG}$ and proteinA on the bacterial cell wall is responsible for the change of colony formation. The inhibition of bacterial capsuleformation of streptococcal bacteria in SSA was caused by the presence of antibody specific to capsule antigens therefore causing the change of colony formation. These results showed that the SSA could also be used to determine the serotype of certain bacteria (Wibawan and Laemmler 1991; Wibawan et al.1992).

In summary, the prototype of the Diagnostic Kit was designed in complex form, using $S$. aureus containing protein A, rabbit sera containing IgG-anti IgY), purified IgY anti-Marek's antibodies and Marek's virus. This complex form is made and optimized using box titration to avoid the self agglutination reactions. This is the most crucial step in preparing the kits and the process is influenced by (i) the titre of $\mathrm{IgG}$ in rabbit sera to IgY, (ii) concentration of protein A of S. aureus, (iii) the titre of IgY to Marek's virus, (iv) the titre of Marek's antigen used, (v) incubation period and (vi) the washing step.

\section{REFERENCES}

Ansorg RA, Zarifoglu FI. 1986. Influence of the cultivation, devitalization and preservation of Staphylococcus aureus ATCC 12598 on the activity of cell-bound protein A. Medical Microbiol Immunol 174:305-12.

Boyle MDP, Reis JJ. 1987. Bacterial Fc receptors. Biol Technol 5:697-703.

Boyle MDP, Wallner WA, von Mering GO, Reis KJ, Lawman MJP. 1985. Interaction of bacterial $\mathrm{Fc}$ receptors with goat immunoglobulins. Molec Immunol 22:1115-21.

Datta SM, Janes E, Simonson JG. 2008. Immunomagnetic separation and coagglutination of Vibrio parahaemolyticus with anti-flagellar protein monoclonal antibody. Clin Vacc Immunol 15:1541-46.

Del Río ML, Gutiérrez CB, Rodríguez FEF. 2003. Value of indirect hemagglutination and coagglutination tests for Serotyping Haemophilus parasuis. J Clin Microbiol 4:880-2.

Djannatun T. 2002. Metode sederhana dan praktis pengujian keberadaan protein A Staphylococcus aureus isolat asal menusia dan sapi perah serta aplikasinya dalam pembuatan perangkat diagnostik. [Dissertation]. Bogor: Program Pascasarjana Institut Pertanian Bogor.

Forsgren A. 1970. Significance of protein A production by staphylococci. Infect Immun 2:672-3.

Jesudason MV, Balaji V, Sirinsinha S, Sridharan G. 2005. Rapid identification of Burkholderia pseudomallei in blood culture supernatants by coagglutination assay. Clin Microbiol Infect 11:930-9.

Kerremans JJ, Goessens WHF, Verbrugh HA, Vos MC. 2008. Rapid identification of Staphyloccocus aureus in positive-testing blood cultures by Slidex Staph Plus Agglutination Test. J Clin Microbiol 46:395. 
Kusunoki H, Hara N, Satto K Hasuda K. 1992. Protein characterization and immunological properties of the low-molecular-mass protein A isolated from Staphylococcus aureus KS 1034. J Vet Med Sci 54:145-8.

Ko KY, Ahn DU. 2007. Preparation of immunoglobulin Y from egg yolk using ammonium sulfate precipitation and ion exchange chromatography. Poult Sci 86:400-7.

Laemmli UK. 1970. Cleavage of structural proteins during the assembly of the head of bacteriophage T4. Nature 227:680-5.

Langone JJ, Boyle MDP, Borsos T. 1978. IgG behaves like IgM immunoglobulin in the presence of protein A. J Immunol 120:1781.

Opdebeeck JP, Watson DL, Frost AJ. 1988. Colony morphology of Staphylococcus aureus in serum-soft agar following in vivo and in vitro growth. Vet Microbiol 16:87-91.

Qian Q, Eichelberger K, Kirby JE. 2007. Rapid identification of Staphylococcus aureus in blood cultures by use of the direct tube coagulase test. J Clin Microbiol 45:2267-69.

Ribeiro MCM, Araújo Jr JP. 2009. Coagglutination for viral DNA preparation of canine parvovirus for molecular diagnosis. J Virol Methods 161:305-7.

Rufli T. 1980. Identification of Neisseria gonorrhoeae in the routine venerelogical laboratory: comparative study of coagglutination, direct immunofluorescence and sugar fermentation reaction. $\mathrm{Br} \mathrm{J}$ Venereal Dis 56:144-7.
Scriba TJ, Sierro S, Brown EL, Phillips RE, Sewell AK, Massey RC. 2008. The Staphyloccous aureus Eap protein activates expression of proinflammatory cytokines. Infect Immun 76:2164-68.

Takase K, Murakawa Y, Ariyoshi R, Eriguchi S, Sugimura T, Fujikawa H. 2000. Serological monitoring on layer farms with specific pathogen-free chickens. J Vet Med Sci 62:1327-29.

Takeuchi S, Matuda K, Sasano K. 1995. Protein A in Staphylococcus aureus isolates from pigs. J Vet Med Sci 57:581-2.

Towbin H, Staehelin T, Gordon J. 1979. Electrophoretic transfer of proteins from polyacrylamide gels to nitrocellulose sheets: procedure and some applications. Proc Natl Acad Sci 76:4350-4.

Wibawan IWT, Lammler C. 1991. Influence of capsul neuraminic acid on properties of Streptococci of Serological Group B. J Gen Microbiol 137:2721-5.

Wibawan IWT, Lämmler C, Pasaribu FH. 1992. Role of hydrophobic surface proteins in mediating adherence of group B streptococci to epithelial cells. J Gen Microbiol 138:1237-42.

Zhou EM, Afshar A, Heckert RA, Nielsen K. 1994. Anti idiotypic antibodies generated by sequential immunization detect the share idiotype on antibodies to seudorabies Virus antigens. J Virol Methods 48:301-13. 